\title{
A multifunctional AIE gold cluster-based theranostic system: tumor-targeted imaging and Fenton reaction-assisted enhanced radiotherapy
}

Yue Hua ${ }^{1}$, Yuan Wang ${ }^{1}$, Xue Kang ${ }^{1}$, Fan Xu' ${ }^{1}$, Zhen Han ${ }^{1}$, Chong Zhang ${ }^{1}$, Zhao-Yang Wang ${ }^{1}$, Jun-Qi Liu², Xueli Zhao ${ }^{1 *}$, Xiaoyuan Chen ${ }^{3,4,5^{*}}$ and Shuang-Quan Zang ${ }^{1 *}$

\begin{abstract}
Background: As cancer is one of the main leading causes of mortality, a series of monotherapies such as chemotherapy, gene therapy and radiotherapy have been developed to overcome this thorny problem. However, a single treatment approach could not achieve satisfactory effect in many experimental explorations.

Results: In this study, we report the fabrication of cyclic RGD peptide (CRGD) modified $\mathrm{Au}_{4}$-iron oxide nanoparticle $\left(\mathrm{Au}_{4}-\mathrm{IO}\right.$ NP-CRGD) based on aggregation-induced emission (AIE) as a multifunctional theranostic system. Besides $\mathrm{Au}_{4}$ cluster-based fluorescence imaging and enhanced radiotherapy, iron oxide $(\mathrm{IO})$ nanocluster could realize magnetic resonance (MR) imaging and Fenton reaction-based chemotherapy. Abundant toxic reactive oxygen species generated from $X$-ray irradiation and in situ tumor-specific Fenton reaction under acidic microenvironment leads to the apoptotic and necrotic death of cancer cells. In vivo studies demonstrated good biocompatibility of $\mathrm{Au}_{4}-\mathrm{IO} N \mathrm{~N}-\mathrm{CRGD}$ and a high tumor suppression rate of $81.1 \%$ in the synergistic therapy group.
\end{abstract}

Conclusions: The successful dual-modal imaging and combined tumor therapy demonstrated AIE as a promising strategy for constructing multifunctional cancer theranostic platform.

Keywords: Aggregation-induced emission (AIE), Assemblies, Radiosensitizer, Therapy, Fenton reaction

\footnotetext{
*Correspondence: xuelizhao@zzu.edu.cn; chen.shawn@nus.edu.sg; zangsqzg@zzu.edu.cn

${ }^{1}$ Henan Key Laboratory of Crystalline Molecular Functional Materials, Henan International Joint Laboratory of Tumor Theranostical Cluster Materials, Green Catalysis Center, and College of Chemistry, Zhengzhou University, Zhengzhou 450001, China

${ }^{3}$ Departments of Diagnostic Radiology, Chemical and Biomolecular Engineering, and Biomedical Engineering, National University of Singapore, Singapore 117545, Singapore

Full list of author information is available at the end of the article
}

(c) The Author(s) 2021. Open Access This article is licensed under a Creative Commons Attribution 4.0 International License, which permits use, sharing, adaptation, distribution and reproduction in any medium or format, as long as you give appropriate credit to the original author(s) and the source, provide a link to the Creative Commons licence, and indicate if changes were made. The images or other third party material in this article are included in the article's Creative Commons licence, unless indicated otherwise in a credit line to the material. If material is not included in the article's Creative Commons licence and your intended use is not permitted by statutory regulation or exceeds the permitted use, you will need to obtain permission directly from the copyright holder. To view a copy of this licence, visit http://creativecommons.org/licenses/by/4.0/. The Creative Commons Public Domain Dedication waiver (http://creativeco mmons.org/publicdomain/zero/1.0/) applies to the data made available in this article, unless otherwise stated in a credit line to the data. 


\section{Graphical Abstract}

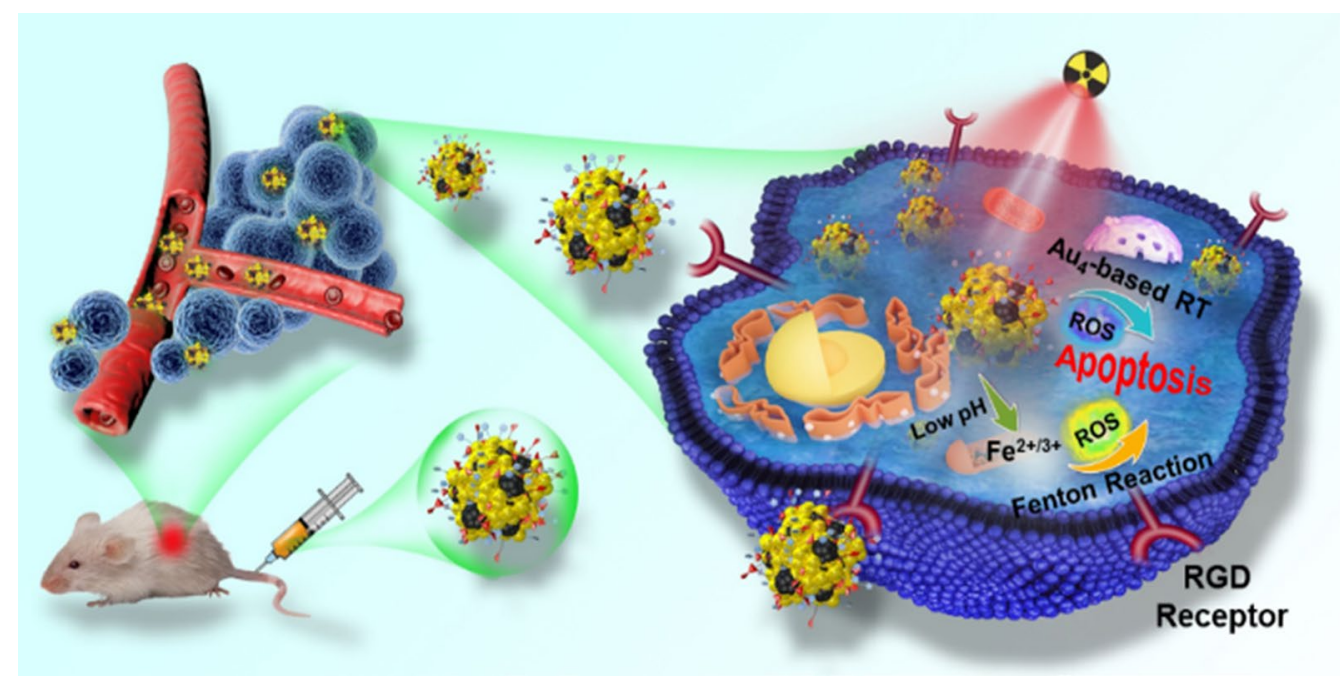

\section{Introduction}

Radiotherapy (RT) could precisely force high-energy $\mathrm{X}$-ray radiation to destroy deep-seated orthotopic tumors. It has been widely used for treatment of local solid tumors such as breast, colorectal, esophageal, lung and brain tumors [1-3]. RT has been applied to over half the cancer patients globally and about $40 \%$ of cancer therapies involve the use of RT, sometimes in combination with other treatments [4-7]. A major and urgent challenge for efficient RT is how to maximize killing effect to cancer cells and in the meantime minimize damage to surrounding healthy tissues [8]. Among a wide range of agents that could affect the radiotherapy efficacy, gold-based nanomaterials remain a dominant candidate to be used for cancer treatment due to their high massattenuation coefficient and low cytotoxicity [9-12]. Besides classical gold nanoparticles (NPs) with large sizes (typically 10-50 nm), fluorescent gold nanoclusters (NCs) (1-3 nm) also emerged and displayed definite radiosensitizing effects [13-18]. For instance, Xie's group explored glutathione (GSH) and bovine serum albumin (BSA)-protected $\mathrm{Au}_{25} \mathrm{NCs}$ as radiosensitizers, demonstrating stronger enhancement for cancer radiotherapy than that of much larger Au NPs [19]. Most recently, Zang's group reported a structurally defined gold-levonorgestrel nanocluster $\mathrm{Au}_{8}\left(\mathrm{C}_{21} \mathrm{H}_{27} \mathrm{O}_{2}\right)_{8}$ as an effective radiosensitizer, pioneering the development of atomically precise $\mathrm{Au}$ NCs (with single crystal structure) based radiotherapy [20].

Reactive oxygen species (ROS) describes the chemical species formed upon incomplete reduction of oxygen, which mainly includes superoxide anion $\left(\mathrm{O}_{2}{ }^{-}\right)$, hydrogen peroxide $\left(\mathrm{H}_{2} \mathrm{O}_{2}\right)$, singlet oxygen $\left({ }^{1} \mathrm{O}_{2}\right)$, and hydroxyl radical $(\cdot \mathrm{OH})[21]$. ROS burst to disrupt the redox homeostasis in tumor cells is one of main mechanisms in cancer therapy [22-24]. It has been found that there is a relatively high concentration of $\mathrm{H}_{2} \mathrm{O}_{2}(\sim 100 \mu \mathrm{M})$ inside the tumor cells [25-28]. Therefore, a series of Fenton reaction-based therapeutic systems involving reductive metal ions and $\mathrm{H}_{2} \mathrm{O}_{2}$ to produce $\cdot \mathrm{OH}$ have been developed [29-32]. For example, superparamagnetic iron oxide (IO) NPs could release iron ions $\left(\mathrm{Fe}^{2+} / \mathrm{Fe}^{3+}\right)$ under acidic conditions and move into cytosol to further affect ROS homeostasis inside cells [33]. However, these cancer therapy strategies are often insufficient due to the limited $\mathrm{H}_{2} \mathrm{O}_{2}$ concentration and ion release rate. Accordingly, developing combination therapies based on several treatment methods is in great demand.

As an efficient way to achieve bright emission from none-emissive single molecules, aggregation-induced emission (AIE) has embodied its superiority in bioimaging and cancer theranostics in the last decade [34-38]. Apart from AIE-active organic molecules, the specific AIE property has also been discovered in metal clusters in recent studies [39-43]. A representative example was chiral alkynyl ligands protected $\mathrm{R} / \mathrm{S}-\mathrm{Cu}_{14} \mathrm{NC}$, which was non-luminescent in dichloromethane (good solvent) but displayed red emission which was further enhanced with the increase of $n$-hexane (poor solvent) fraction [40]. The effectiveness of RT depends on the generation of ROS through radiolysis, and excessive ROS could overwhelm the antioxidant capacity of cells and cause cells death. In this case, we have studied the combination of RT and Fenton reaction to increase ROS yield through AIE 


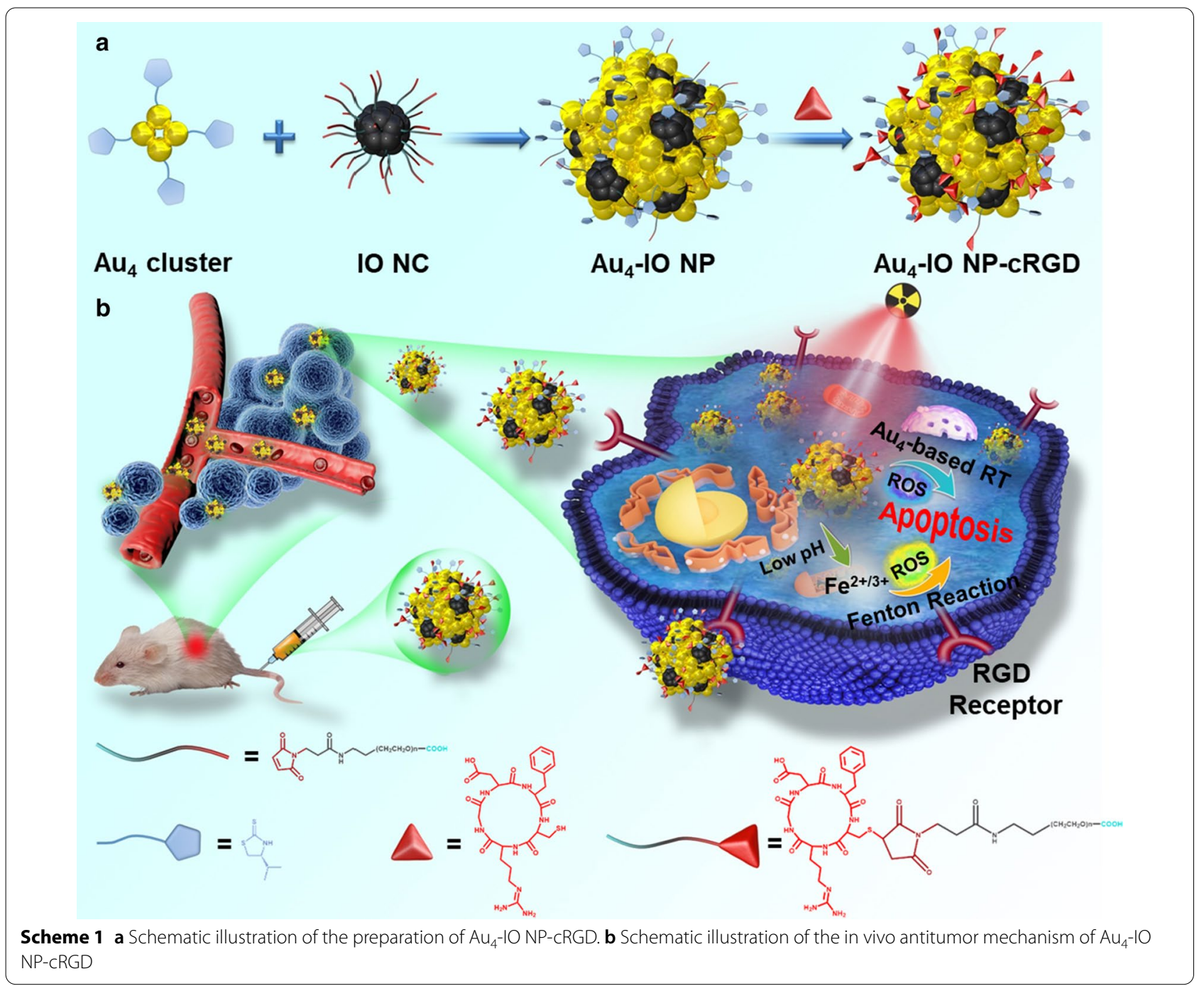

technology. In addition, it has been demonstrated that AIEgens can also provide effective ROS generation in the aggregated state, which might promote energy transfer from the lowest excited singlet state (S1) to the lowest triplet state (T1) due to the prohibition of energy dissipation through non-radiative channels [44, 45]. Herein, we proposed green emissive $\mathrm{Au}_{4}$-IO NP assemblies based on AIE management in which non-fluorescent $\mathrm{Au}_{4}$ cluster solution assembled with IO NC in PBS buffer due to aurophilicity (Scheme 1a). With modification of cyclic arginine-glycine-aspartic-phenylalanine-cysteine acid (cRGD) peptide, $\mathrm{Au}_{4}$-IO NP-cRGD could achieve good targeting effect against $\alpha_{v} \beta_{3}$-integrin overexpressing tumor cells. In the as-designed multifunctional $\mathrm{Au}_{4}-\mathrm{IO}$ NP-cRGD assemblies, $\mathrm{Au}_{4}$ cluster could produce abundant ROS upon X-ray irradiation, and IO NC could increase the amount of $\cdot \mathrm{OH}$ based on Fenton reaction
(Scheme 1b), finally resulting in synergistic irreversible damage to cancer cells. In the meantime, the fluorescence of aggregated $\mathrm{Au}_{4}$ cluster and magnetic property of IO $\mathrm{NC}$ could realize fluorescence and magnetic resonance (MR) imaging of tumors in vivo. The simple $\mathrm{Au}_{4}$-IO NPcRGD assemblies based on AIE exhibited effective targeted Fenton reaction assisted enhanced radiotherapy.

\section{Experimental}

\section{Synthesis of $\mathrm{Au}_{4}-\mathrm{IO} \mathrm{NP}-\mathrm{CRGD}$}

$\mathrm{Au}_{4}$ cluster $(2 \mathrm{mM})$ was dissolved in DMF and then diluted with ethanol to $125 \mu \mathrm{M}$. $50 \mu \mathrm{M}$ PEG modifiedIO NC in PBS was added into ethanol solution of $\mathrm{Au}_{4}$ cluster with a volume ratio (IO NC: $\mathrm{Au}_{4}$ cluster) of $6: 4$ for uniform oscillation. For the conjugation of cRGD on the surface of $\mathrm{Au}_{4}-\mathrm{IO} \mathrm{NP}, \mathrm{cRGD}(10 \mathrm{mg} / \mathrm{mL}$, dissolved in DMSO) was added into aqueous suspension of $\mathrm{Au}_{4}-\mathrm{IO}$ 
NP with uniform oscillation. Then, aqueous suspension was centrifuged ( $8000 \mathrm{rpm}$ for $5 \mathrm{~min}$ ) to remove free gold clusters and IO NC for further utilization.

\section{Cytotoxicity analysis}

4T1 cells were seeded into 96-well plates at a density of approximately $10^{4}$ cells per well and cultured in RPMI1640 medium supplemented with $10 \%$ fetal bovine serum at $37{ }^{\circ} \mathrm{C}$ in a humidified incubator with $5 \% \mathrm{CO}_{2}$. After cell attachment, the cell medium was then replaced with $100 \mu \mathrm{L}$ fresh medium containing different concentrations of $\mathrm{Au}_{4}-\mathrm{IO} \mathrm{NP} / \mathrm{Au}_{4}-\mathrm{IO} N P-c R G D(0,1,2.5$, and $5 \mu \mathrm{M})$. The detailed dilution procedure: $2 \mathrm{mM} \mathrm{Au}_{4}$ cluster stock solution in DMF was firstly diluted with ethanol to $125 \mu \mathrm{M}$, and then $50 \mu \mathrm{M}$ PEG modified-IO NC in cell culture medium was added into the above prepared $\mathrm{Au}_{4}$ cluster solution with a volume ratio (IO NC: $\mathrm{Au}_{4}$ cluster) of 6:4 to produce $\mathrm{Au}_{4}$-IO NP. After cRGD functionalization, $\mathrm{Au}_{4}$-IO NP-cRGD was diluted with cell culture medium for cytotoxicity assay. The control group was cell culture medium containing 0.04\% DMF and 1.56\% ethanol. After $24 \mathrm{~h}, \mathrm{CCK}-8$ reagent $(10 \mu \mathrm{L}$ per well) was added to the wells and incubated for $1 \mathrm{~h}$. The absorbance at $450 \mathrm{~nm}$ was measured using a SpectraMax absorbance reader. The relative cell viability (\%) was calculated as follows: $\left(\mathrm{A}_{\text {test }} / \mathrm{A}_{\text {control }}\right) \times 100$.

\section{Cell imaging}

4T1 cells were cultured on glass-bottomed Petri dishes at an initial density of $2 \times 10^{4}$ cells/dish. $12 \mathrm{~h}$ later, the cell medium was replaced with fresh medium containing $\mathrm{Au}_{4}$-IO NP-cRGD or $\mathrm{Au}_{4}$-IO NP $\left(\mathrm{Au}_{4}\right.$ content, $\left.2 \mu \mathrm{M}\right)$ for incubation. Confocal images of the cells were acquired with a Leica TCS SP8 confocal fluorescence microscope (excited at $405 \mathrm{~nm}$ ).

\section{Colony formation assay}

4T1 cells were seeded in cell culture dishes (35 $\mathrm{mm} \times 12 \mathrm{~mm})$ and incubated overnight for cell attachment. Then, the cells were divided into control group (without addition of nanomaterials) and treatment groups $\left(2 \mu \mathrm{M} \mathrm{Au}_{4}\right.$-IO NP/Au $\mathrm{Au}_{4}$-IO NP-cRGD). $6 \mathrm{~h}$ later, the cells were treated with different doses of X-ray (320 kV; 0, 2, 4, and 6 Gy) irradiation, and macroscopic cell colonies formed after 2 weeks. The cell colonies were fixed with $4 \%$ paraformaldehyde and stained with $0.2 \%$ crystal violet for counting. Each group was analyzed in triplicate and counted by Image J software. The cell survival fraction was calculated as the ratio of the number of colonies formed in treated wells to the number of colonies formed in untreated well (no materials and no X-ray). The cell survival curve was estimated by a multi-target single-hit model $\left(\mathrm{S}=1-\left(1-\mathrm{e}^{-\mathrm{D} / \mathrm{D} 0}\right)^{\mathrm{n}}\right.$ and then $\mathrm{D}_{0}$ and $\mathrm{n}$ were calculated by the Sigma Plot 12.0 software. The SER was expressed with the following formulae: $\mathrm{SER}=\mathrm{D}_{\mathrm{q}}$ (control group) $/ \mathrm{D}_{\mathrm{q}}$ (treated group) and $\mathrm{D}_{\mathrm{q}}=\ln (\mathrm{n}) \times \mathrm{D}_{0}$, where $\mathrm{D}_{\mathrm{q}}$ is the quasi-threshold dose. The control group was cell culture medium containing $0.04 \%$ DMF and $1.56 \%$ ethanol.

\section{Live/dead imaging}

4T1 cells were cultured on glass-bottomed Petri dishes with an initial density of $4 \times 10^{4}$ cells/dish. The same setup of cloning assay was applied with the live/dead assay until X-ray treatment. After X-ray irradiation, cells were cultured for another $24 \mathrm{~h}$ before viability assay. $4 \mathrm{~T} 1$ cells were stained with a LIVE/DEAD cell imaging kit according to the manufacturer's instructions. Confocal images were taken with a Leica TCS SP8 confocal fluorescence microscope (excited at 488 and $552 \mathrm{~nm}$ ).

\section{Intracellular caspase-3/7 imaging}

4T1 cells were seeded in glass-bottomed Petri dishes at an initial density of $2 \times 10^{4}$ cells/dish overnight and incubated with nanomaterials $\mathrm{Au}_{4}-\mathrm{IO} \mathrm{NP} / \mathrm{Au}_{4}-\mathrm{IO} \mathrm{NP}-\mathrm{cRGD}$ of $2 \mu \mathrm{M}$ for $6 \mathrm{~h}$ followed by irradiation at 0 and $4 \mathrm{~Gy}$ $\mathrm{X}$-ray. After $24 \mathrm{~h}$, the cells were stained with the CellEvent $^{\mathrm{TM}}$ Caspase-3/7 Green Reagent. Confocal images were taken with a Leica TCS SP8 confocal fluorescence microscope (excitation: $488 \mathrm{~nm}$ ).

\section{Flow cytometric assay}

$4 \mathrm{~T} 1$ cells with a density of $2 \times 10^{5}$ cells/well were first cultured in 6-well plates overnight. After complete attachment, the cells were incubated with $\mathrm{Au}_{4}-\mathrm{IO} \mathrm{NP} /$ $\mathrm{Au}_{4}$-IO NP-cRGD $(2 \mu \mathrm{M})$ for $6 \mathrm{~h}$. Then, the cells were irradiated by X-ray ( 0 and $4 \mathrm{~Gy}$ ) and further cultured for $24 \mathrm{~h}$ before washing and collection. Annexin V-FITC/ PI double staining was used for apoptosis analysis using flow cytometry.

\section{Intracellular DNA break}

4T1 cells were cultured on glass-bottomed petri dishes for incubation of materials and X-ray treatment. $24 \mathrm{~h}$ later, the cells were fixed with $4 \%$ paraformaldehyde and permeated with $0.25 \%$ Triton X-100. Then, the cells were blocked with $1 \%$ bovine serum albumin (BSA) for $1 \mathrm{~h}$ and incubated with $\gamma-\mathrm{H} 2 \mathrm{AX}$ antibody (MA5-33062, Invitrogen) overnight at $4{ }^{\circ} \mathrm{C}$. Ultimately, the secondary antibody Alexa Fluor ${ }^{\mathrm{TM}} 647$ tag goat anti-rabbit IgG $(\mathrm{H}+\mathrm{L})$ (A21245, Invitrogen) was added for $1 \sim 2 \mathrm{~h}$, and DAPI was used to stain cell nuclei. The cells were imaged using Leica TCS SP8 confocal fluorescence microscope at excitation wavelengths of 405 and $647 \mathrm{~nm}$. 


\section{Intracellular $\cdot \mathrm{OH}$ detection}

4T1 cells were cultured on glass-bottomed petri dishes and treated with or without $\mathrm{Au}_{4}-\mathrm{IO} \mathrm{NP} / \mathrm{Au}_{4}-\mathrm{IO} \mathrm{NP}$ cRGD $(2 \mu \mathrm{M})$. After $6 \mathrm{~h}$, the medium was removed, and then the prepared test solution (OH580 Stain Working solution) was added and incubated for $1 \mathrm{~h}$ at $37^{\circ} \mathrm{C}$. Then these groups were treated with or without X-ray (4 Gy). Finally, the cells were stained with DAPI, and imaged using Leica TCS SP8 confocal fluorescence microscope at excitation wavelengths of 405 and $540 \mathrm{~nm}$.

\section{Animals and tumor model}

All animal procedures were conducted in accordance with the Guide for Care and Use of Laboratory Animals and were approved by the Institutional Animal Care and Use Committee of the Zhengzhou University. BALB/c SPF mice (5-week-old females) were housed in a controlled environment with a $12 \mathrm{~h} / 12 \mathrm{~h}$ light/dark cycle. A maximum of five animals were housed together and provided with food and water ad libitum. The mouse breast cancer cell line 4T1 is widely used as a syngeneic tumor model of breast cancer. 4T1 tumors were established by subcutaneously injecting approximately $5 \times 10^{6} 4 \mathrm{~T} 1$ cells. When the tumor reached a volume of $\sim 150 \mathrm{~mm}^{3}$, the mice were used for biodistribution and cancer therapy studies.

\section{Biodistribution}

4T1 tumor-bearing mice were randomly divided into four groups followed by an intravenous injection of $100 \mu \mathrm{L}$ of $\mathrm{Au}_{4}$-IO NP-cRGD $(10 \mathrm{mg} / \mathrm{kg})$. The mice were euthanized at $6,24,48 \mathrm{~h}$, and 7 days after injection of materials, and the tumors and major organs were harvested. Then, the tumors and major organs were dispersed in $5 \mathrm{~mL} \mathrm{HNO}_{3}$ overnight and digested with $5 \mathrm{~mL}$ of $30 \% \mathrm{H}_{2} \mathrm{O}_{2}$ under boiling at $200{ }^{\circ} \mathrm{C}$. The amounts of $\mathrm{Au}$ in each sample were measured using ICP-MS.

\section{In vivo imaging}

Tumor-bearing mice were intravenous injected with $\mathrm{Au}_{4}-\mathrm{IO} \quad \mathrm{NP}-\mathrm{cRGD} \quad(10 \mathrm{mg} / \mathrm{kg})$. Fluorescence imaging was conducted at 6 and $48 \mathrm{~h}$ post-injection using a PerkinElmer IVIS Spectrum in vivo imaging system. Imaging parameters were as follows: binning factor $=8$, aperture $=2$, exposure time $=2$ s,excitation filter $=430$, emission filter $=520$. For in vivo $M R$ imaging, tumorbearing mice were anesthetized by isoflurane (3\%) in oxygen and placed in an animal-specific body coil. MR images were acquired at $0,6,24$, and $48 \mathrm{~h}$ after intravenous injection of $\mathrm{Au}_{4}$-IO NP-cRGD $(10 \mathrm{mg} / \mathrm{kg})$ or saline (as control) using a MR SOLUTIONS MRS-4717 system.
Imaging parameters were as follows: echo spacing $=17$, echo train $=7$, slices $=18$, slice thickness $=1 \mathrm{~mm}$, FOV ratio $=1, \mathrm{FOV}=18 \times 35 \mathrm{~mm}^{2}$.

\section{Cancer therapy}

Murine breast cancer cell line 4T1 was widely used as a syngeneic tumor model of breast cancer, which was the tumor entity with the highest incidence in the world. 4T1 tumor-bearing mice were weighed and randomly divided into five groups: (1) Control, (2) $\mathrm{Au}_{4}-\mathrm{IO} \mathrm{NP}-$ cRGD, (3) 4 Gy, (4) $\mathrm{Au}_{4}-\mathrm{IO} \mathrm{NP}+4 \mathrm{~Gy}$, and (5) $\mathrm{Au}_{4}-\mathrm{IO}$ NP-cRGD +4 Gy. Then, $100 \mu \mathrm{L}$ of saline was intravenous injected into the mice in group 1 and 3 , while the mice in group 2 and 5 or group 4 were intravenous injected with $100 \mu \mathrm{L} \mathrm{Au} \mathrm{u}_{4}$-IO NP-cRGD or $\mathrm{Au}_{4}$-IO NP $(10 \mathrm{mg} / \mathrm{kg})$ every 3 days for 14 days, respectively. Afterwards, the mice were subjected to X-ray irradiation $4 \mathrm{~Gy}$ at $48 \mathrm{~h}$ after injection. The mice were photographed and their body weights were measured every other day for 14 days. Also, the length (L) and width (W) of the tumors were measured to calculate the tumor volume $(\mathrm{V})$ according to the following equation: $\mathrm{V}=\mathrm{L} \times \mathrm{W}^{2} / 2$.

\section{Evaluation of in vivo radiotherapy toxicity}

At day 15 after the treatment, all mice were killed, and their peripheral blood and organs were collected for serum biochemistry analysis and pathological investigation respectively. The hearts, livers, spleens, lungs, kidneys, and tumors were fixed in $10 \%$ neutral formalin solution overnight. Then, the samples were embedded in paraffin blocks, sectioned into $5 \mu \mathrm{m}$ slices, and mounted onto glass slides. After H\&E staining, images were acquired with a Leica DMi1 inverted microscope.

\section{Statistical analysis}

All data were collected in at least triplicate and represented as means $\pm S D$. Differences between two groups were examined by the two-tailed Student's $t$ test. Significant differences were noted with asterisks as $P<0.05$ (*) or $P<0.01$ (**).

\section{Results and discussion}

Preparation and characterization of $\mathrm{Au}_{4}-\mathrm{IO} N$ P-cRGD

$\mathrm{Au}_{4}\left(\mathrm{C}_{6} \mathrm{H}_{10} \mathrm{~S}_{2} \mathrm{~N}\right)_{4}$ cluster and PEG modified iron oxide nanocluster (IO NC) were synthesized at a high yield according to published methods [46]. The phase purity of $\mathrm{Au}_{4}$ cluster was confirmed by powder X-ray diffraction (PXRD) (Additional file 1: Fig. S1). Coordination of the rhombic-like $\mathrm{Au}_{4}$ core was shown in Fig. 1e: Each ligand bridges one side of $\mathrm{Au}_{4}$ rhombus by a thiol $\mathrm{S}$ atom and an $\mathrm{N}$ atom from top and down. Intercluster $\mathrm{Au}-\mathrm{Au}$ interactions and weak intercluster interactions among the ligands fasten the $\mathrm{Au}_{4}$ units, which collectively suppress 

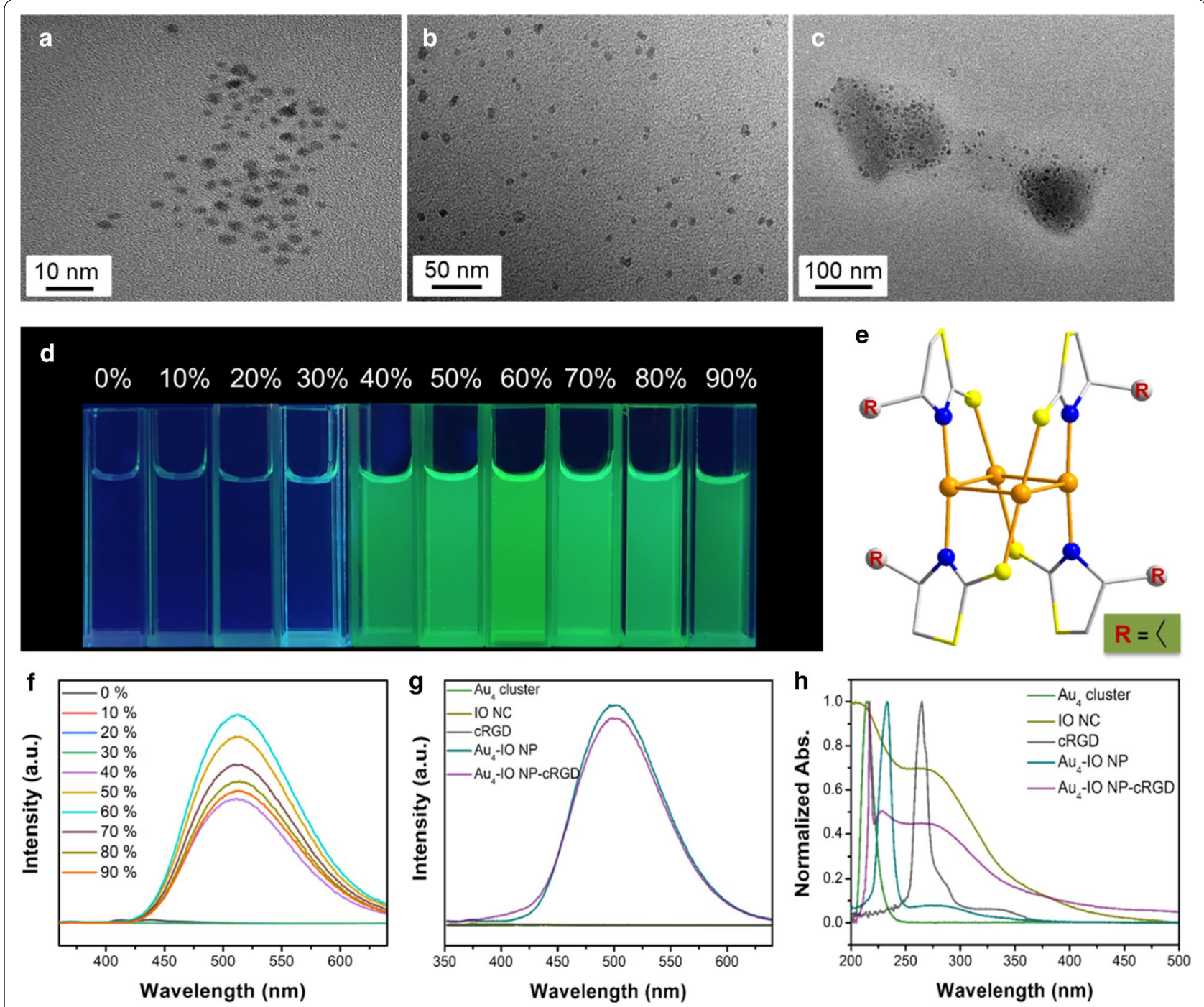

Fig. 1 TEM images of a $\mathrm{Au}_{4}$ cluster, b PEG modified IO NC, and $\mathbf{c} \mathrm{Au}_{4}-\mathrm{OO}$ NP. $\mathbf{d}$ Fluorescence photographs of $\mathrm{Au}_{4}$ cluster in dimethylformamide (DMF) with different fractions of IO NC in PBS under UV light. e The overall structures of $\mathrm{Au}_{4}$ cluster revealed by single-crystal X-ray analysis. Color codes: orange indicates $\mathrm{Au}$, yellow indicates $\mathrm{S}$, blue indicates $\mathrm{N}$ and gray indicates $\mathrm{C}$. Hydrogen atoms were omitted for clarity. $\mathbf{f}$ Emission spectra of $\mathrm{Au}_{4}$ cluster in DMF with different fractions of IO NC in PBS. $\mathbf{g}$ Emission spectra and $\mathbf{h} U V$-vis spectra of $A u_{4}$ cluster, IO NC, $C R G D, A u_{4}-I O N P$, and $\mathrm{Au}_{4}-\mathrm{IO} \mathrm{NP}-\mathrm{CRGD}$

nonradiative transitions and hinder intracluster motions in the aggregated state, resulting in aggregation-induced emission (AIE) [39]. $\mathrm{Au}_{4}$-IO nanoparticles (NPs) were acquired by mixing $\mathrm{Au}_{4}$ cluster in organic phase and IO $\mathrm{NC}$ in aqueous solution, then cRGD was linked to PEG ligand of IO NC for cancer cell targeting (Scheme 1a; details in the Experimental Section). The size of the $\mathrm{Au}_{4}$-IO NP-cRGD was approximately $100 \mathrm{~nm}$, in which the sizes of $\mathrm{Au}_{4}$ cluster and IO NC were around 2 and $7 \mathrm{~nm}$ (Fig. 1a-c and Additional file 1: Fig. S2), respectively. Dynamic light scattering (DLS) measurements of the PEG modified IO $\mathrm{NC}$ and $\mathrm{Au}_{4}$ cluster (Additional file 1: Fig. S3a, b) also confirmed a relatively narrow size distribution with good dispersibility. AIE experiments showed that the non-emissive solution of $\mathrm{Au}_{4}$ cluster showed intense green emission centered at $510 \mathrm{~nm}$ when the fraction of poor solvent $\left(\mathrm{H}_{2} \mathrm{O}\right)$ rose to $40 \%$ (Fig. $1 \mathrm{~d}$, f). The fluorescence intensity continued to increase and plateaued at $60 \% \mathrm{H}_{2} \mathrm{O}$ content. At the same time, the size increase of aggregates with increasing $\mathrm{H}_{2} \mathrm{O}$ fraction was also confirmed by DLS analysis (Additional file 1: Fig. S3). Notebly, in cell culture medium, the size of $\mathrm{Au}_{4}-\mathrm{IO} N \mathrm{NP}$ (IO NC: $\mathrm{Au}_{4}$ cluster $=6: 4$ ) is stable at about $100 \mathrm{~nm}$, even if the assemblies were further diluted with cell medium 
(Additional file 1: Fig. S4). $\mathrm{Au}_{4}-\mathrm{IO} \mathrm{NP}$ and $\mathrm{Au}_{4}-\mathrm{IO} \mathrm{NP}-$ cRGD showed similar fluorescence spectra with emission peaks at approximately $510 \mathrm{~nm}$ (Fig. $1 \mathrm{~g}$ ). As shown in Fig. $1 \mathrm{~h}, \mathrm{UV}$-vis spectrum of the as-fabricated $\mathrm{Au}_{4}$-IO NPcRGD comprised all the characteristic absorbance peaks of $\mathrm{Au}_{4}$ cluster, IO NC, and cRGD (i.e., around $217 \mathrm{~nm}$, $229 \mathrm{~nm}$, and $263 \mathrm{~nm}$ ). After conjugation of cRGD peptide, the zeta potential of NP increased from $-12.03 \mathrm{mV}$ $\left(\mathrm{Au}_{4}\right.$-IO NP) to $3.83 \mathrm{mV}\left(\mathrm{Au}_{4}\right.$-IO NP-cRGD) (Additional file 1: Fig. S6). Moreover, ${ }^{1} \mathrm{H}$ NMR and Diffusion Ordered NMR SpectroscopY (DOSY) also confirmed the successful modification of cRGD peptide (Additional file 1: Figs. S7, S8) [47]. At the same time, the stability of $\mathrm{Au}_{4}-\mathrm{IO}$ $\mathrm{NP}$-cRGD in the blood was investigated, considering that they were intravenous injected (Additional file 1: Fig. S5). The fluorescence emission peak of $\mathrm{Au}_{4}$-IO NP-cRGD in serum exhibited little red-shift (510 nm to $520 \mathrm{~nm}$ ). DLS measurements of $\mathrm{Au}_{4}$-IO NP-cRGD in serum confirmed a relatively narrow size distribution.

\section{Cytotoxicity and in vitro radiosensitizing effects}

To evaluate the in vitro cytotoxicity of $\mathrm{Au}_{4}$-IO NP-cRGD as a radiosensitizer, we measured the relative cell viabilities of mouse breast cancer cells (4T1) with and without $\mathrm{X}$-ray irradiation through a CCK-8 assay kit. As depicted in Fig. $2 \mathrm{a}$, both the $\mathrm{Au}_{4}-\mathrm{IO} \mathrm{NP}$ and $\mathrm{Au}_{4}$-IO NP-cRGD displayed a dose-dependent cytotoxicity against $4 \mathrm{~T} 1$ cells, and $\mathrm{Au}_{4}$-IO NP-cRGD was slightly more toxic due to the targeting effect of cRGD. Additional X-ray irradiation caused enhanced proliferation inhibition of cells treated with $\mathrm{Au}_{4}-\mathrm{IO} \mathrm{NP} / \mathrm{Au}_{4}-\mathrm{IO} \mathrm{NP}-\mathrm{cRGD}$ (Additional file 1: Fig. S10). Confocal imaging results revealed that cells incubated with $\mathrm{Au}_{4}-\mathrm{IO} \mathrm{NP}-\mathrm{cRGD}\left(2 \mu \mathrm{M}, \mathrm{IC}_{10}\right)$ showed brighter fluorescence than that of $\mathrm{Au}_{4}-\mathrm{IO} \mathrm{NP}$
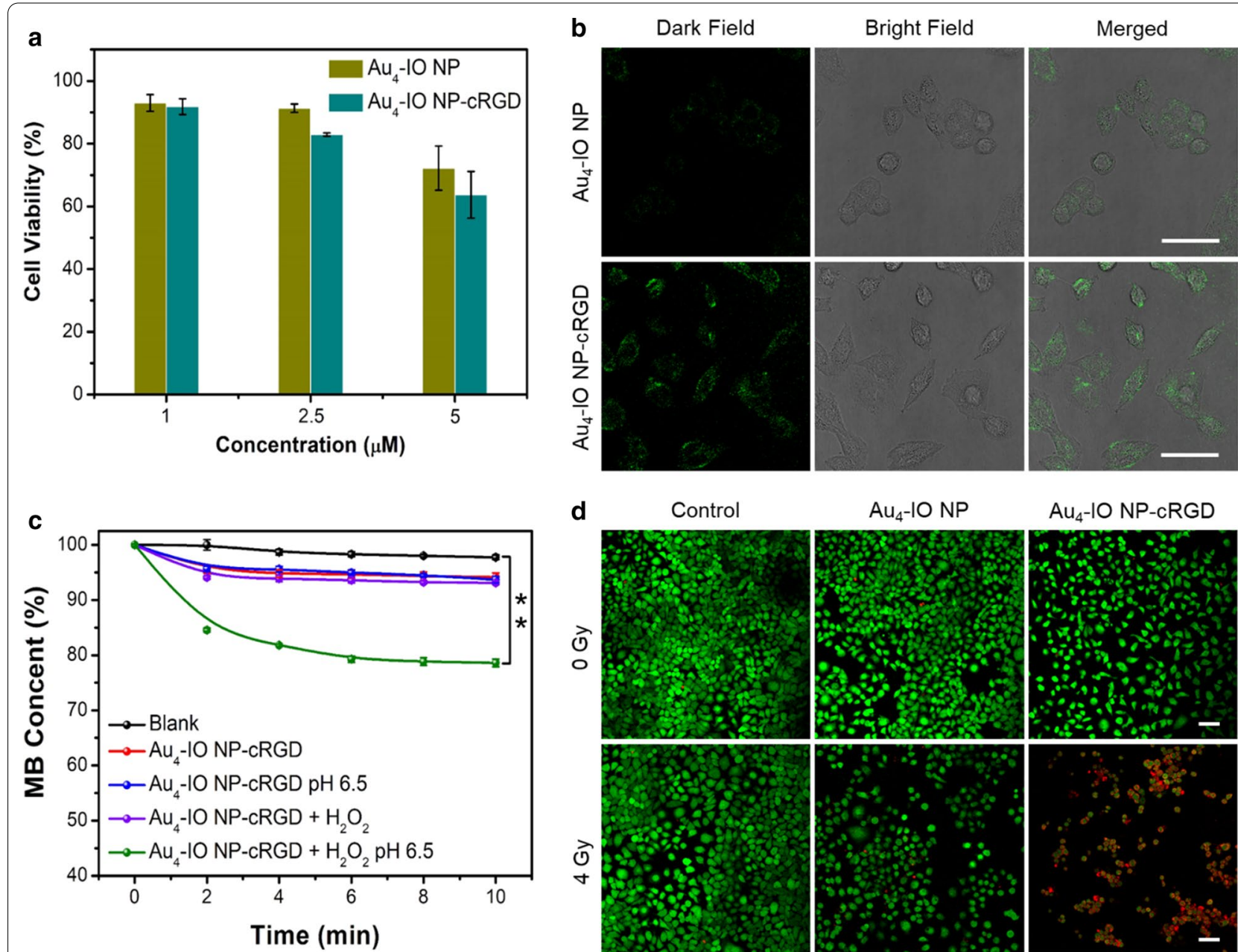

$\mathrm{Au}_{4}-\mathrm{IO} N P-\mathrm{CRGD}$

Fig. 2 a In vitro cytotoxicity against 4T1 cells of $\mathrm{Au}_{4}-\mathrm{IO} N P / \mathrm{Au}_{4}-\mathrm{IO} N \mathrm{NP}-\mathrm{CRGD}$. $\mathbf{b}$ Confocal imaging of $4 T 1$ cells after incubation with $\mathrm{Au}_{4}-\mathrm{IO} N \mathrm{NP}$ and $\mathrm{Au}_{4}-\mathrm{IO} \mathrm{NP-CRGD}(2 \mu \mathrm{M})$. Scale bar: $50 \mu \mathrm{m}$. c Time-dependent $\cdot \mathrm{OH}$ generation from $\mathrm{Au}_{4}-\mathrm{IO}$ NP-CRGD with various treatments. $\mathbf{d} \mathrm{Live/dead}$ imaging of $4 \mathrm{~T} 1$ cells after receiving different treatments (control group, $4 \mathrm{~Gy} X$-ray, $\mathrm{Au}_{4}-\mathrm{IO} N \mathrm{NP}, \mathrm{Au}_{4}-\mathrm{IO} \mathrm{NP}-\mathrm{CRGD}, \mathrm{Au}_{4}-\mathrm{IO} \mathrm{NP}+4 \mathrm{~Gy} X-\mathrm{ray}_{\text {, and } \mathrm{Au}}-\mathrm{IO}$ NP-cRGD + 4 Gy X-ray). Green: live; red: dead. Scale bar: $50 \mu m$. ${ }^{* *} P<0.01$ 
treated cells (Fig. 2b) and flow cytometry showed that the fluorescence intensity of $\mathrm{Au}_{4}-\mathrm{IO} \mathrm{NP}-\mathrm{RGD}$ treated cells was higher than that treated with $\mathrm{Au}_{4}-\mathrm{IO} \mathrm{NP}$ (Additional file 1: Fig. S9), demonstrating more efficient cellular uptake owing to the effective molecular targeting capacity of cRGD to $\alpha_{\mathrm{v}} \beta_{3}$ integrin on the surface of cancer cells.[48-52]. In addition, there is no fluorescent signal in IO NC group. Due to the AIE property of $\mathrm{Au}_{4}$ cluster, a few fluorescent signals but weaker than $\mathrm{Au}_{4}-\mathrm{IO}$ $\mathrm{NP}$-cRGD group could be seen in $\mathrm{Au}_{4}$ group (Additional file 1: Fig. S11). Besides gold based radiosensitization, -OH generated by Fenton reaction played a significant role in chemotherapy, initiated by free ferrous ions $\left(\mathrm{Fe}^{2+} /\right.$ $\mathrm{Fe}^{3+}$ ) from IO NC in this study. Methylene blue (MB) was employed to quantify the $\cdot \mathrm{OH}$ production efficiency [25]. Compared with the $\mathrm{Au}_{4}-\mathrm{IO}$ NP-cRGD $+\mathrm{H}_{2} \mathrm{O}_{2}$ group (decreased to 93.1\%) and $\mathrm{Au}_{4}$-IO NP-cRGD group at $\mathrm{pH}$ 6.5 (decreased to 93.7\%), the UV absorbance of $\mathrm{MB}$ in the $\mathrm{Au}_{4}$-IO NP-cRGD $+\mathrm{H}_{2} \mathrm{O}_{2}$ group at $\mathrm{pH} 6.5$ decreased to $78.6 \%$ (Fig. 2c), which was mainly due to the fact that $\mathrm{Fe}_{3} \mathrm{O}_{4}$ was decomposed under acidic conditions to produce $\mathrm{Fe}^{2+} / \mathrm{Fe}^{3+}$, and $\mathrm{Fe}^{2+}$ could react with $\mathrm{H}_{2} \mathrm{O}_{2}$ to produce toxic $\cdot \mathrm{OH}$. When cells were treated with $2 \mu \mathrm{M}$ $\mathrm{Au}_{4}$-IO NP-cRGD along with the addition of $100 \mu \mathrm{M}$ $\mathrm{H}_{2} \mathrm{O}_{2}$ in the acidified medium ( $\mathrm{pH}$ 6.5), substantial cytotoxicity was observed due to Fenton reaction based $\bullet \mathrm{OH}$ generation (Additional file 1: Fig. S12). Calcein acetoxymethylester (Calcine AM) and propidium iodide (PI) were used to monitor live (green) and dead (red) states of cells before and after X-ray irradiation [53]. As illustrated in Fig. 2d, cells of control and material only groups exhibited good viability, confirming the low toxicity of $\mathrm{Au}_{4}-\mathrm{IO}$ NP-cRGD at this concentration. Notably, death rate of cells incubated with $\mathrm{Au}_{4}$-IO NP-cRGD upon X-ray irradiation displayed a dose-dependent increase (Fig. 2d, Fig. S13).

Annexin V/PI assay [47] based on flow cytometry was performed to investigate cellular apoptosis during $\mathrm{Au}_{4}-\mathrm{IO} \mathrm{NP}$-cRGD enhanced RT. The sum of necrosis and apoptosis ratio of $4 \mathrm{~T} 1$ cells treated by $\mathrm{Au}_{4}$-IO NP-cRGD or X-ray alone was $13.38 \%$ and $16.15 \%$, respectively. (Fig. 3a and Additional file 1: Figs. S14-S17), while the combination of $\mathrm{Au}_{4}$-IO NP-cRGD and X-ray irradiation increased to $34.28 \%$. Compared with $\mathrm{Au}_{4}-\mathrm{IO} \mathrm{NP}+4$ Gy group, cells in $\mathrm{Au}_{4}$-IO NP-cRGD+4 Gy group exhibited a higher necrosis rate. A cell colony formation assay was conducted to further assess the enhanced radiotherapy effect of $\mathrm{Au}_{4}$-IO NP-cRGD over a longer period of time. The corresponding results revealed similar dosedependent radiosensitization effect (Fig. 3b, Additional file 1: Figs. S18, S19). The sensitization enhancement ratio (SER, calculated by $\mathrm{SER}=\mathrm{D}_{\mathrm{q}}$ (Control group) $/ \mathrm{D}_{\mathrm{q}}$ (Treated group)) $[54,55]$ of $\mathrm{Au}_{4}-\mathrm{IO}$ NP-cRGD for $4 \mathrm{~T} 1$ cells was calculated to be 1.573 (Fig. 3b), which was slightly higher than that of the commonly used Au drug auranofin (1.462) [35]. In addition, the SER of $\mathrm{Au}_{4}-\mathrm{IO}$ NP for 4T1 cells was calculated to be 1.436 (Additional file 1: Fig. S19). These results suggest that the as-prepared $\mathrm{Au}_{4}$-IO NP-cRGD have a remarkable cell-killing ability under X-ray irradiation, making it a promising candidate for highly effective RT.

To further explore the therapeutic mechanism of $\mathrm{Au}_{4}$-IO NP-cRGD based RT, the cellular $\cdot \mathrm{OH}$ generation after treatment with different NPs was first detected by a mitochondrial $\bullet \mathrm{OH}$ detection assay kit [56]. As shown in Fig. $3 \mathrm{c}$ and Additional file 1: Fig. S20, the mean fluorescence intensity of $\cdot \mathrm{OH}$ indicator in the $\mathrm{Au}_{4}$-IO NPcRGD + X-ray treated group was slightly higher than that of $\mathrm{Au}_{4}-\mathrm{IO} \mathrm{NP}+\mathrm{X}$-ray group, achieving 4.4 and 7.1 times of fluorescence intensity of 4 Gy and $\mathrm{Au}_{4}-\mathrm{IO} \mathrm{NP}$ cRGD group, respectively. Meanwhile, DNA damage of 4T1 cells after treating with $\mathrm{Au}_{4}$-IO NP-cRGD and X-ray was tested by immunofluorescence staining of $\gamma-\mathrm{H} 2 \mathrm{AX}$, a marker of double-stranded DNA damage $[57,58]$. Very weak red fluorescence signals were detected in cells of control, $\mathrm{Au}_{4}$-IO NP-cRGD, and X-ray groups, representing the ignorable DNA break. Notably, 4T1 cells treated with $\mathrm{Au}_{4}$-IO NP-cRGD + X-ray exhibited the brightest red fluorescence signals, indicating a higher DNA damage level than $\mathrm{Au}_{4}-\mathrm{IO} \mathrm{NP}+\mathrm{X}$-ray group (Fig. 3d, Additional file 1: Figs. S21, and S22). Afterwards, the activation of caspase-3/7 (apoptosis marker) was determined using Caspase-3/7 Green ReadyProbes ${ }^{\mathrm{TM}}$ Kit, which consisted of the DEVD peptide sequence conjugated to a nucleic acid-binding dye. In the presence of activated caspase $3 / 7$, the dye would be cleaved from the DEVD peptide and became free to bind DNA, producing a fluorogenic response. Obvious fluorescence was detected in the $\mathrm{Au}_{4}$-IO NP-cRGD+4 Gy X-ray group, and there was almost no green fluorescence in the control and $\mathrm{Au}_{4}$-IO NP-cRGD groups (Fig. 3e and Additional file 1: Fig. S23). Above mentioned results demonstrated that the as-prepared $\mathrm{Au}_{4}$-IO NP-cRGD could induce abundant $\cdot \mathrm{OH}$ production, serious DNA damage and effective caspase $3 / 7$ activation under X-ray irradiation, resulting in enhanced therapeutic efficiency of $\mathrm{Au}_{4}-\mathrm{IO}$ NP-cRGD based RT. Additionally, previouly reported Au NCs affected thioredoxin reductase (TrxR) activity could also be a possible mechanism for the synergetic treatment effect $[35,59]$.

\section{Biodistribution and in vivo therapy}

Subsequently, in vivo performance of $\mathrm{Au}_{4}-\mathrm{IO} N P$-cRGD in tumor imaging and therapy was explored. Firstly, the biodistribution of $\mathrm{Au}_{4}$-IO NP-cRGD in 4T1 tumor-bearing mice was monitored by inductively coupled plasma 


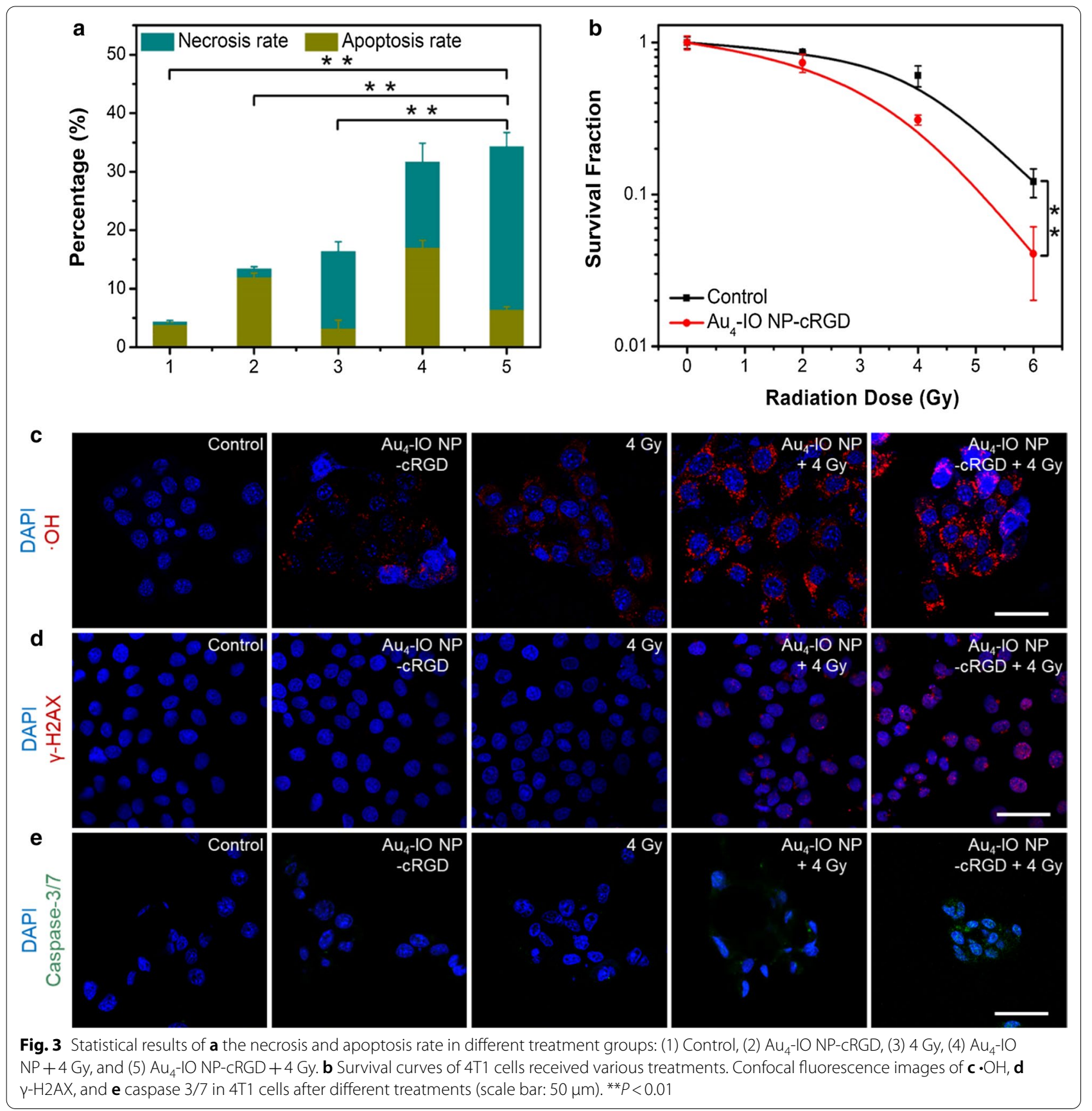

mass spectrometry (ICP-MS) via determination of Au. As shown in Additional file 1: Fig. S24, $\mathrm{Au}_{4}-\mathrm{IO} \mathrm{NP} / \mathrm{Au}_{4}-\mathrm{IO}$ NP-cRGD accumulation in the tumor site achieved maximum at $48 \mathrm{~h}$ post-injection $(10 \mathrm{mg} / \mathrm{kg})$. After intravenous injection of $\mathrm{Au}_{4}-\mathrm{IO} \mathrm{NP}-\mathrm{cRGD}$ or saline, MR imaging data were acquired at $0,6,24$ and $48 \mathrm{~h}$ time points with a $4.7 \mathrm{~T}$ system. T2-weighted images displayed targeted signal from $\mathrm{Au}_{4}-\mathrm{IO} \mathrm{NP}-\mathrm{cRGD}$ in tumor (Fig. 4a). Then, we have tried fluorescence imaging due to the high QY of $40.5 \%$ in the aggregated state. Fluorescence imaging acquired by PerkinElmer IVIS system displayed similar result (Fig. 4b). Both MR and fluorescence imaging confirmed that $\mathrm{Au}_{4}$-IO NP-cRGD could effectively accumulate in 4T1 tumors. Following successful tumor-targeted imaging, we then investigated in vivo antitumor activities of $\mathrm{Au}_{4}-\mathrm{IO}$ NP-cRGD. Due to the weakly acidic extracellular tumor microenvironment and over expression of hydrogen peroxide in both intra- and extracellular tumor 


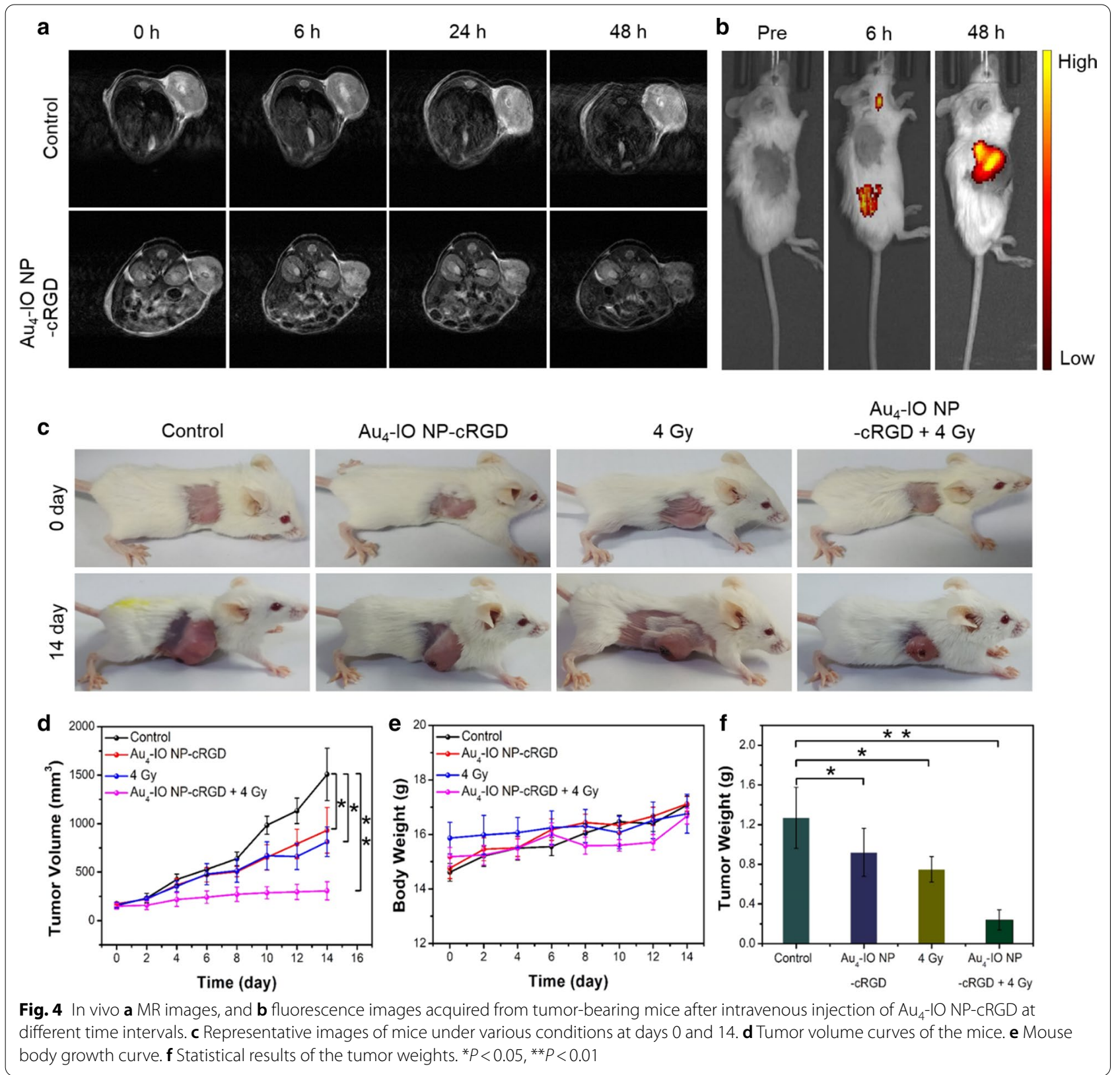

microenvironment, $\mathrm{Au}_{4}$-IO NP-cRGD could activate endogenous $\mathrm{H}_{2} \mathrm{O}_{2}$ to produce $\cdot \mathrm{OH}$ in tumor site (Fenton reaction), playing a supplementary role in Au based enhanced RT. 4T1 tumor-bearing mice were treated with an experimental procedure as follows: mice were intravenous injected with $\mathrm{Au}_{4}$-IO NP-cRGD every three days and exposed to X-ray (4 Gy) at $48 \mathrm{~h}$ post injection (for 5 times in total). As shown in Fig. 4c, 4T1 tumors in control group (treated with saline) grew exponentially, while tumors treated with $\mathrm{Au}_{4}-\mathrm{IO} \mathrm{NP}-\mathrm{cRGD}$ and X-ray irradiation were significantly suppressed. Compared with the control group, the inhibition rates of tumor volume and tumor weight in synergistic therapy group reached $79.7 \%$ and $81.1 \%$, respectively (Fig. $4 \mathrm{~d}, \mathrm{f}$ and Additional file 1 : Fig. S25). In addition, the body weights of all mice were in normal range (Fig. 4e). In contrast, $\mathrm{Au}_{4}-\mathrm{IO} \mathrm{NP}$ (lack of targeting function) resulted lower accumulation efficiency in tumors and relatively poor in vivo radiotherapy effect (Additional file 1: Fig. S26).

To assess the systemic toxicity of the as-prepared $\mathrm{Au}_{4}$-IO NP-cRGD in tumor treatment, serum biochemistry analysis and hematoxylin and eosin (H\&E) staining of the main organ of mice were performed after 14 days treatment. Blood biochemical tests showed that 
the levels of cholesterol (CHOL), albumin (ALB), aminotransferase (AST), urea nitrogen (BUN), creatinine (CREA), and lactate dehydrogenase (LDH-L) in the $\mathrm{Au}_{4}$-IO NP-cRGD + X-ray group were similar to those in control group mice (Fig. 5a-f), and no histopathological abnormalities in the main organs were observed (Fig. 5g). In contrast, widespread damage was observed in the tumor tissue from the $\mathrm{Au}_{4}-\mathrm{IO} \mathrm{NP}-\mathrm{cRGD}+\mathrm{X}$-ray group compared with the other three groups. These data further demonstrated the significant synergistic therapy
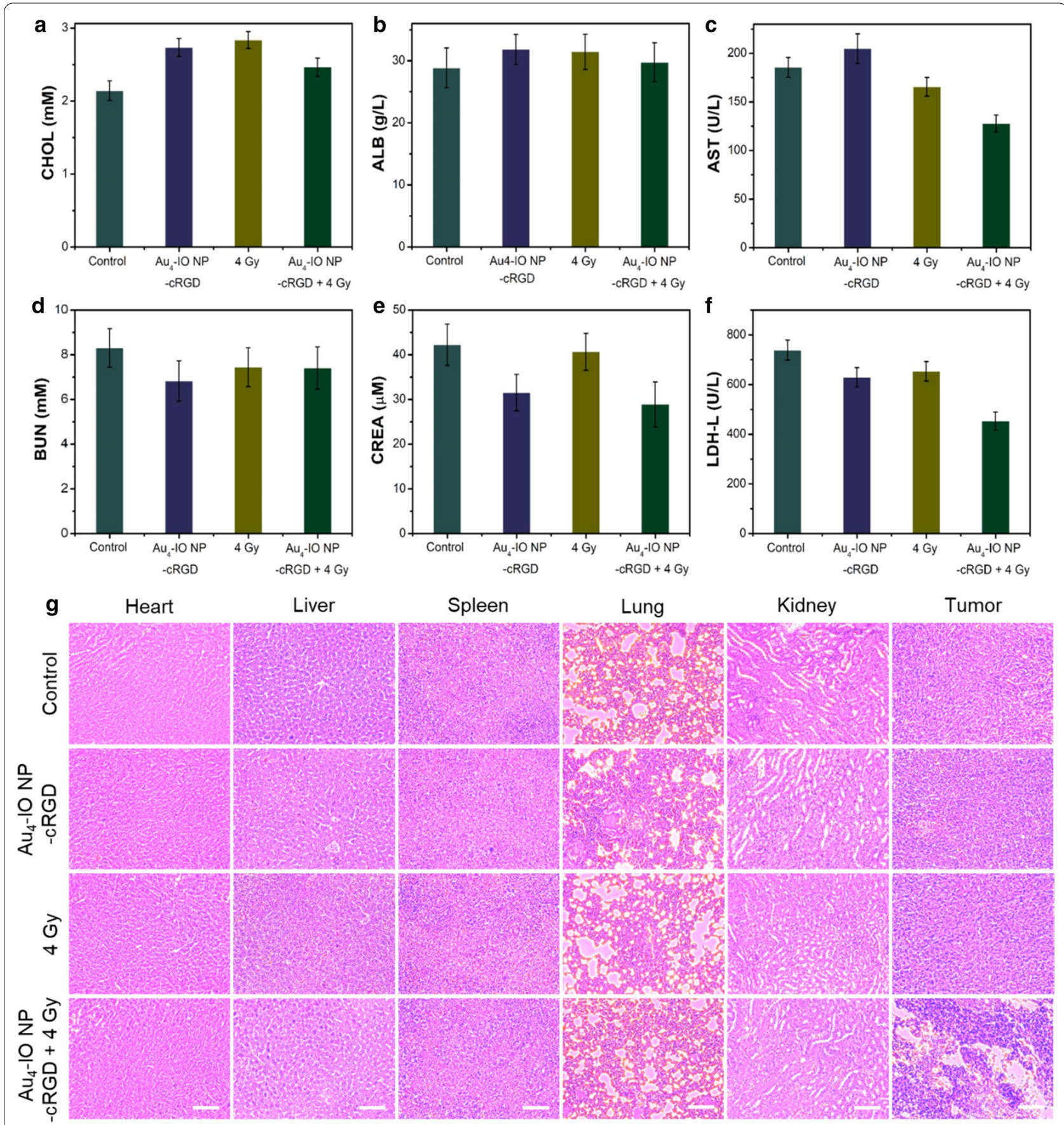

Fig. 5 a-f Serum biochemistry analysis of tumor-bearing mice with different treatments: a cholesterol (CHOL), b albumin (ALB), c aminotransferase (AST), $\mathbf{d}$ blood urea nitrogen (BUN), e creatinine (CREA), and $\mathbf{f}$ lactate dehydrogenase (LDH-L). $\mathbf{g}$ H\&E histological staining of excised organs and tumor slices. Scale bar: $200 \mu \mathrm{m}$ 
effect and in vivo biosafety of the as-prepared $\mathrm{Au}_{4}-\mathrm{IO}$ NP-cRGD in Fenton reaction-assisted enhanced radiation therapy.

\section{Conclusions}

In summary, green emissive $\mathrm{Au}_{4}-\mathrm{IO} \mathrm{NP}$-cRGD with active cancer cell-targeting property was prepared based on AIE strategy to realize dual-modal imaging guided Fenton reaction-assisted enhanced radiotherapy. Firstly, the $\mathrm{Au}_{4}$ cluster composition in the assemblies played a vital role in enhancing the radiotherapy effect upon $\mathrm{X}$-ray irradiation. Secondly, the IO NC composition in the assemblies could catalyze the in situ decomposition of the overexpressed $\mathrm{H}_{2} \mathrm{O}_{2}$ in tumor cells via Fenton reaction to produce $\cdot \mathrm{OH}$, further augmenting tumor therapy effect. ROS from these two parts resulted in DNA damage and up-regulation of caspase-3/7. In vivo therapy studies revealed a tumor suppression rate of $81.1 \%$ in the Fenton catalysis assisted enhanced radiotherapy. The successful dual-modal imaging and combined tumor therapy demonstrated AIE as a promising strategy for constructing multifunctional cancer theranostic platform.

\begin{abstract}
Abbreviations
CRGD: Cyclic RGD peptide; $\mathrm{Au}_{4}-\mathrm{IO}$ NP-CRGD: $\mathrm{CRGD}$ modified $\mathrm{Au}_{4}$-iron oxide nanoparticle; IO: Iron oxide; IO NC: Iron oxide nanocluster; AIE: Aggregationinduced emission; MR: Magnetic resonance; RT: Radiotherapy; NPs: Nanoparticles; NCs: Nanoclusters; GSH: Glutathione; BSA: Bovine serum albumin; ROS: Reactive oxygen species; DLS: Dynamic light scattering; DMF: Dimethylformamide; MB: Methylene blue; 4T1: Mouse breast cancer cells; Calcine AM: Calcein acetoxymethylester; PI: Propidium iodide; H\&E: Hematoxylin and eosin; CHOL: Cholesterol; ALB: Albumin; AST: Aminotransferase; BUN: Urea nitrogen; CREA: Creatinine; LDH-L: Lactate dehydrogenase.
\end{abstract}

\section{Supplementary Information}

The online version contains supplementary material available at https://doi. org/10.1186/s12951-021-01191-x.

Additional file 1: Fig. S1. PXRD patterns of $\mathrm{Au}_{4}$ cluster. Fig. S2. TEM image of oil-phase IO NCs. Fig. S3. DLS spectra of (a) PEG modified IO $\mathrm{NC}$ and $\mathrm{Au}_{4}$ cluster in DMF with (b) 0\% PBS, (c) 20\% PBS, (d) 40\% PBS, and (e) $60 \%$ PBS, (f) $80 \%$ PBS. Fig. S4. DLS spectra of (a) $\mathrm{Au}_{4}-\mathrm{IO}$ NP in DMF/ ethanol with $60 \%$ medium and (b) 1000 times diluted $\mathrm{Au}_{4}-1 \mathrm{O} N \mathrm{NP}$ using cell medium. Fig. S5. Emission spectra and (b) DLS spectra of $\mathrm{Au}_{4}-\mathrm{IO}$ NP-CRGD in serum at day $0,3,5$, and 7. Fig. S6. Zeta potential of $\mathrm{Au}_{4}-1 \mathrm{O} N \mathrm{NP}$ and $\mathrm{Au}_{4}-\mathrm{IO}$ NP-CRGD. Fig. S7. ${ }^{1} \mathrm{H}-\mathrm{NMR}$ spectra of $\mathrm{CRGD}-\mathrm{PEG}-\mathrm{COOH}$. The characteristic peak of CRGD and PEG confirm the structure of CRGD-PEG$\mathrm{COOH}$. Fig. S8. ${ }^{1} \mathrm{H}-\mathrm{NMR}$ spectrum and DOSY spectrum of CRGD-PEG$\mathrm{COOH}$. Fig. S9. Flow cytometric assay of 4T1 cells after incubation with PBS, $\mathrm{Au}_{4}-\mathrm{IO} N \mathrm{NP}$ and $\mathrm{Au}_{4}-\mathrm{IO}$ NP-RGD. Fig. S10. In vitro cytotoxicity against $4 \mathrm{~T} 1$ cells of $\mathrm{Au}_{4}-\mathrm{IO} \mathrm{NP}$ and $\mathrm{Au}_{4}-\mathrm{OO} N \mathrm{NP}-\mathrm{CRGD}$ with $4 \mathrm{~Gy} \mathrm{X}$-ray irradiation. Fig. S11. Confocal imaging of $4 \mathrm{~T} 1$ cells after incubation with $\mathrm{Au}_{4}$ and $\mathrm{IO}$ NC. Scale bar: $50 \mu \mathrm{m}$. Fig. S12. Viability of $4 \mathrm{~T} 1$ cells in different treatment groups: (1) $\mathrm{Au}_{4}-\mathrm{IO} N \mathrm{NP}-\mathrm{cRGD}$, (2) pH 6.5, (3) $\mathrm{H}_{2} \mathrm{O}_{2}$, (4) $\mathrm{Au}_{4}-\mathrm{IO} \mathrm{NP}-\mathrm{cRGD} \mathrm{pH}$ 6.5, (5) $\mathrm{Au}_{4}-\mathrm{IO} \mathrm{NP}-\mathrm{CRGD}+\mathrm{H}_{2} \mathrm{O}_{2}$, and (6) $\mathrm{Au}_{4}-\mathrm{OO} \mathrm{NP}-\mathrm{CRGD}+\mathrm{H}_{2} \mathrm{O}_{2} \mathrm{pH} 6.5$. Fig. S13. Live/dead imaging of $4 \mathrm{~T} 1$ cells after receiving different treatments (2 Gy X-ray, Au $u_{4}-1 \mathrm{O} N P+2$ Gy X-ray, and Au-IO NP-cRGD + 2 Gy $X$-ray). Green: live; red: dead. Scale bar: 50 um. Fig. S14. Flow cytometric assay of 4T1 cells (negative control, positive control). Fig. S15. Flow cytometric assay of $4 \mathrm{~T} 1$ cells with different treatments (batch 1). Fig. S16. Flow cytometric assay of $4 \mathrm{~T} 1$ cells with different treatments (batch 2). Fig. S17. Flow cytometric assay of $4 \mathrm{~T} 1$ cells with different treatments (batch 3). Fig. S18. Representative images of the colony formation assay of $4 \mathrm{~T} 1$ cells with different treatments. Fig. S19. Survival curve of 4T1 cells received $\mathrm{Au}_{4}-\mathrm{OO}$ NP. Fig. S20. The fluorescence intensity of hydroxyl radical imaging of $4 \mathrm{~T} 1$ cells $\left(\lambda_{\mathrm{ex}}=540 \mathrm{~nm}\right)$ at $6 \mathrm{~h}$ after administering different treatments. (1) Control, (2) $\mathrm{Au}_{4}-\mathrm{IO} N \mathrm{NP}-\mathrm{CRGD}$, (3) $4 \mathrm{~Gy}$, (4) $\mathrm{Au}_{4}-\mathrm{IO} \mathrm{NP}+4 \mathrm{~Gy}$, and (5) $\mathrm{Au}_{4}-\mathrm{IO} \mathrm{NP}-\mathrm{CRGD}+4 \mathrm{~Gy}$. Fig. S21. Confocal images of $\mathrm{Y}-\mathrm{H} 2 \mathrm{AX}$ expression in $4 \mathrm{~T} 1$ cells after receiving various treatments. Scale bar: $50 \mu \mathrm{m}$. Fig. $\mathbf{S 2 2}$. The fluorescence intensity of $\gamma$-H2AX imaging of $4 \mathrm{~T} 1$ cells $\left(\lambda_{e x}=647 \mathrm{~nm}\right)$ at $6 \mathrm{~h}$ after administering different treatments. (1) Control, (2) $\mathrm{Au}_{4}-\mathrm{IO}$ NP-CRGD, (3) $4 \mathrm{~Gy}$, (4) $\mathrm{Au}_{4}-\mathrm{IO} \mathrm{NP}+4 \mathrm{~Gy}$, and (5) $\mathrm{Au}_{4}-\mathrm{IO} \mathrm{NP}-\mathrm{CRGD}+4 \mathrm{~Gy}$. Fig. S23. The fluorescence intensity of Caspase-3/7 imaging of $4 \mathrm{~T} 1$ cells $\left(\lambda_{e x}=488 \mathrm{~nm}\right)$ at $6 \mathrm{~h}$ after administering different treatments. (1) Control, (2) $\mathrm{Au}_{4}-\mathrm{IO} N \mathrm{NP}-\mathrm{CRGD}$, (3) $4 \mathrm{~Gy}$, (4) $\mathrm{Au}_{4}-\mathrm{IO} \mathrm{NP}+4 \mathrm{~Gy}$, and (5) $\mathrm{Au}_{4}-\mathrm{IO} \mathrm{NP}-$ CRGD + 4 Gy. Fig. S24. The biodistribution of (a) $\mathrm{Au}_{4}-\mathrm{IO} N \mathrm{NP}$ and (b) $\mathrm{Au}_{4}-\mathrm{IO}$ NP-cRGD at $6 h, 24 h, 48 h, 72 h$, and $7 d$ after intravenous injection. Fig. S25. (a) Images of dissected tumors in control, $A_{4}-I O N P-C R G D$, and $\mathrm{Au}_{4}-\mathrm{IO} N \mathrm{~N}-\mathrm{CRGD}+4 \mathrm{~Gy}$. (b) Images of dissected tumors in $4 \mathrm{~Gy}$ group. Fig. S26. (a) Representative images of mice of $\mathrm{Au}_{4}-\mathrm{IO} N \mathrm{NP}+4 \mathrm{~Gy}$ group at days 0 and 14. (b) Tumor volume curve of the mice. (c) Mouse body growth curve. (d) Image of dissected tumors in $\mathrm{Au}_{4}-\mathrm{IO}+4 \mathrm{~Gy}$.

\section{Acknowledgements}

Not applicable.

\section{Authors' contributions}

YH: investigation, methodology, data curation, validation, writing-original draft. YW: validation. XK: Validation. FX: Validation. ZH: Methodology, Supervision. CZ: Software. Z-YW: Methodology, Supervision. J-QL: Methodology, Supervision, Resources. XZ: Conceptualization, Investigation, Methodology, Supervision, Writing-review and editing, Funding acquisition. XC: Supervision, Writing-review and editing, Funding acquisition. S-QZ: Supervision, Writingreview and editing, Funding acquisition. All authors read and approved the final manuscript.

\section{Funding}

This work was supported by the National Science Fund for Distinguished Young Scholars (No. 21825106), the key project of National Natural Science Foundation of China (No. 92061201), the National Natural Science Foundation of China (No. 22001235), the China Postdoctoral Science Foundation (No. 2019M652562), the Program for Science and Technology Innovation Talents in Universities of Henan Province (No. 164100510005) and Zhengzhou University, the National University of Singapore Start-up Grant (NUHSRO/2020/133/ Startup/08) and NUS School of Medicine Nanomedicine Translational Research Programme (NUHSRO/2021/034/TRP/09/Nanomedicine).

\section{Availability of data and materials}

All data analyzed during this study are included in this published article and its additional file.

\section{Declarations}

\section{Ethics approval and consent to participate}

All animal procedures were conducted in accordance with the Guide for Care and Use of Laboratory Animals and were approved by the Institutional Animal Care and Use Committee of the Zhengzhou University.

\section{Consent for publication}

All authors consent for publication.

\section{Competing interests}

All authors declared no competing interests.

\section{Author details}

${ }^{1}$ Henan Key Laboratory of Crystalline Molecular Functional Materials, Henan International Joint Laboratory of Tumor Theranostical Cluster Materials, Green 
Catalysis Center, and College of Chemistry, Zhengzhou University, Zhengzhou 450001, China. ${ }^{2}$ The First Affiliated Hospital of Zhengzhou University, Zhengzhou 450000, China. ${ }^{3}$ Departments of Diagnostic Radiology, Chemical and Biomolecular Engineering, and Biomedical Engineering, National University of Singapore, Singapore 117545 , Singapore. ${ }^{4} \mathrm{Clinical}$ Imaging Research Centre, Centre for Translational Medicine, Yong Loo Lin School of Medicine, National University of Singapore, Singapore 117599, Singapore. ${ }^{5}$ Nanomedicine Translational Research Program, NUS Center for Nanomedicine, Yong Loo Lin School of Medicine, National University of Singapore, Singapore 117597, Singapore.

Received: 22 September 2021 Accepted: 7 December 2021

Published online: 20 December 2021

\section{References}

1. Fan W, Lu N, Shen Z, Tang W, Shen B, Cui Z, Shan L, Yang Z, Wang Z, Jacobson $O$. Generic synthesis of small-sized hollow mesoporous organosilica nanoparticles for oxygen-independent $\mathrm{X}$-ray-activated synergistic therapy. Nat Commun. 2019;10:1241.

2. Haume K, Rosa S, Grellet S, Smialek MA, Butterworth KT, Solov'yov AV, Prise KM, Golding J, Mason NJ. Gold nanoparticles for cancer radiotherapy: a review. Cancer Nanotechnol. 2016;7:8.

3. Song G, Cheng L, Chao Y, Yang K, Liu Z. Emerging nanotechnology and advanced materials for cancer radiation therapy. Adv Mater. 2017;29:1700996

4. Cao J, Shi X, Gurav DD, Huang L, Su H, Li K, Niu J, Zhang M, Wang Q, Jiang M, Qian K. Metabolic fingerprinting on synthetic alloys for medulloblastoma diagnosis and radiotherapy evaluation. Adv Mater. 2020:32:2000906

5. Liu J, Hu F, Wu M, Tian L, Gong F, Zhong X, Chen M, Liu Z, Liu B. Bioorthogonal coordination polymer nanoparticles with aggregation-induced emission for deep tumor-penetrating radio- and radiodynamic therapy. Adv Mater. 2021;33:2007888

6. Sharma RA, Plummer R, Stock JK, Greenhalgh TA, Ataman O, Kelly S, Clay R, Adams RA, Baird RD, Billingham L. Clinical development of new drugradiotherapy combinations. Nat Rev Clin Oncol. 2016;13:627-42.

7. Bian Z, Shi L, Kidder K, Zen K, Charlie G-B, Liu Y. Intratumoral SIRPadeficient macrophages activate tumor antigen-specific cytotoxic $T$ cells under radiotherapy. Nat Commun. 2021;12:3229.

8. Fu W, Zhang X, Mei L, Zhou R, Yin W, Wang Q, Gu Z, Zhao Y. Stimuliresponsive small-on-large nanoradiosensitizer for enhanced tumor penetration and radiotherapy sensitization. ACS Nano. 2020;14:10001-17.

9. Chen X, Song J, Chen X, Yang H. X-ray-activated nanosystems for theranostic applications. Chem Soc Rev. 2019:48:3073-101.

10. Cheng K, Sano M, Jenkins CH, Zhang G, Vernekohl D, Zhao W, Wei C, Zhang Y, Zhang Z, Liu Y. Synergistically enhancing the therapeutic effect of radiation therapy with radiation activatable and reactive oxygen species-releasing nanostructures. ACS Nano. 2018;12:4946-58.

11. Luo D, Wang X, Zeng S, Ramamurthy G, Burda C, Basilion JP. Targeted gold nanocluster-enhanced radiotherapy of prostate cancer. Small. 2019;15:1900968.

12. Xia D, Hang D, Li Y, Jiang W, Zhu J, Ding Y, Gu H, Hu Y. Au-hemoglobin loaded platelet alleviating tumor hypoxia and enhancing the radiotherapy effect with low-dose X-ray. ACS Nano. 2020;14:15654-68.

13. Franze B, Engelhard C. Fast separation, characterization, and speciation of gold and silver nanoparticles and their ionic counterparts with micellar electrokinetic chromatography coupled to ICP-MS. Anal Chem. 2014;86:5713-20.

14. Jin R, Zeng C, Zhou M, Chen Y. Atomically precise colloidal metal nanoclusters and nanoparticles: fundamentals and opportunities. Chem Rev. 2016;116:10346-413.

15. Kang X, Li Y, Zhu M, Jin R. Atomically precise alloy nanoclusters: syntheses, structures, and properties. Chem Soc Rev. 2020;49:6443-514.

16. Liu L, Corma A. Metal catalysts for heterogeneous catalysis: from single atoms to nanoclusters and nanoparticles. Chem Rev. 2018;118:4981-5079.

17. Zhang XD, Luo Z, Chen J, Shen X, Song S, Sun Y, Fan S, Fan F, Leong DT, Xie J. Ultrasmall $\mathrm{Au}_{(10-12)}(\mathrm{SG})_{(10-12)}$ nanomolecules for high tumor specificity and cancer radiotherapy. Adv Mater. 2014;26:4565-8.
18. Zheng $Y$, Wu J, Jiang H, Wang X. Gold nanoclusters for theranostic applications. Coord Chem Rev. 2021;431:213689.

19. Zhang XD, Chen J, Luo Z, Wu D, Shen X, Song SS, Sun YM, Liu PX, Zhao J, Huo $S$. Enhanced tumor accumulation of sub- $2 \mathrm{~nm}$ gold nanoclusters for cancer radiation therapy. Adv Healthc Mater. 2014;3:133-41.

20. Jia TT, Yang G, Mo SJ, Wang ZY, Li BJ, Ma W, Guo YX, Chen X, Zhao X, Liu $\mathrm{JQ}$, Zang SQ. Atomically precise gold-levonorgestrel nanocluster as a radiosensitizer for enhanced cancer therapy. ACS Nano. 2019;13:8320-8.

21. Zhou Z, Song J, Nie L, Chen X. Reactive oxygen species generating systems meeting challenges of photodynamic cancer therapy. Chem Soc Rev. 2016;45:6597-626.

22. Liu H, Duan X, Lv Y-K, Zhu L, Zhang Z, Yu B, Jin Y, Si Y, Wang Z, Li B, Peng P. Encapsulating metal nanoclusters inside porous organic cage towards enhanced radio-sensitivity and solubility. Chem Eng J. 2021;426:130872

23. Yang B, Chen Y, Shi J. Reactive oxygen species (ROS)-based nanomedicine. Chem Rev. 2019;119:4881-985.

24. Zhang W, Hu X, Shen Q, Xing D. Mitochondria-specific drug release and reactive oxygen species burst induced by polyprodrug nanoreactors can enhance chemotherapy. Nat Commun. 2019;10:1704.

25. Hou H, Huang X, Wei G, Xu F, Wang Y, Zhou S. Fenton reaction-assisted photodynamic therapy for cancer with multifunctional magnetic nanoparticles. ACS Appl Mater Interfaces. 2019;11:29579-92.

26. Kim J, Cho HR, Jeon H, Kim D, Song C, Lee N, Choi SH, Hyeon T. Continuous $\mathrm{O}_{2}$-evolving $\mathrm{MnFe}_{2} \mathrm{O}_{4}$ nanoparticle-anchored mesoporous silica nanoparticles for efficient photodynamic therapy in hypoxic cancer. J Am Chem Soc. 2017;139:10992-5.

27. Gao L, Zhang Y, Zhao L, Niu W, Tang Y, Gao F, Cai P, Yuan Q, Jiang H, Gao $X$. An artificial metalloenzyme for catalytic cancer-specific DNA cleavage and operando imaging. Sci Adv. 2020;6: eabb1421.

28. Liu Y, Zhen W, Jin L, Zhang S, Sun G, Zhang T, Xu X, Song S, Wang Y, Liu J, Zhang H. All-in-one theranostic nanoagent with enhanced reactive oxygen species generation and modulating tumor microenvironment ability for effective tumor eradication. ACS Nano. 2018;12:4886-93.

29. Dai Y, Yang Z, Cheng S, Wang Z, Zhang R, Zhu G, Wang Z, Yung BC, Tian R, Jacobson O. Toxic reactive oxygen species enhanced synergistic combination therapy by self-assembled metal-phenolic network nanoparticles. Adv Mater. 2018:30:1704877.

30. Fan JX, Peng MY, Wang H, Zheng HR, Liu ZL, Li CX, Wang XN, Liu XH, Cheng SX, Zhang XZ. Engineered bacterial bioreactor for tumor therapy via fenton-like reaction with localized $\mathrm{H}_{2} \mathrm{O}_{2}$ generation. Adv Mater. 2019;31:1808278.

31. Lin LS, Song J, Song L, Ke K, Liu Y, Zhou Z, Shen Z, Li J, Yang Z, Tang W. Simultaneous Fenton-like ion delivery and glutathione depletion by $\mathrm{MnO}_{2}$-based nanoagent to enhance chemodynamic therapy. Angew Chem Int Ed. 2018;57:4902-6.

32. Qian $X$, Zhang J, Gu Z, Chen Y. Nanocatalysts-augmented Fenton chemical reaction for nanocatalytic tumor therapy. Biomaterials. 2019;211:1-13.

33. Song J, Lin L, Yang Z, Zhu R, Zhou Z, Li ZW, Wang F, Chen J, Yang H, Chen $X$. Self-assembled responsive bilayered vesicles with adjustable oxidative stress for enhanced cancer imaging and therapy. J Am Chem Soc. 2019:141:8158-70

34. Chen C, Song Z, Zheng X, He Z, Liu B, Huang X, Kong D, Ding D, Tang BZ. AlEgen-based theranostic system: targeted imaging of cancer cells and adjuvant amplification of antitumor efficacy of paclitaxel. Chem Sci. 2017:8:2191-8.

35. Zhang J, Zou H, Lei J, He B, He X, Herman HYS, Ryan TKK, Jacky WYL, Zheng L, Tang BZ. Multifunctional Au'-based AIEgens: manipulating molecular structures and boosting specific cancer cell imaging and theranostics. Angew Chem Int Ed. 2020;59:7097-105.

36. Tavakkoli Yaraki M, Wu M, Middha E, Wu W, Daqiqeh Rezaei S, Liu B, Tan YN. Gold nanostars-AIE theranostic nanodots with enhanced fluorescence and photosensitization towards effective image-guided photodynamic therapy. Nano-Micro Lett. 2021;13:58.

37. Li Y, Ni H, Zhang H, Zhang H, Clarence C, Chao Ma KSW, Jacky WYL, Ryan TKK, Qian J, Lu X, Tang BZ. ACQ-to-AIE transformation: tuning molecular packing by regioisomerization for two-photon NIR bioimaging. Angew Chem, Int Ed. 2020;59:12822-6.

38. Kang M, Zhang Z, Song N, Li M, Sun P, Chen X, Wang D, Tang BZ. Aggregation-enhanced theranostics: AIE sparkles in biomedical field. Aggregate. 2020;1:80-106 
39. Han Z, Zhao X, Peng P, Li S, Zhang C, Cao M, Li K, Wang Z-Y, Zang S-Q. Intercluster aurophilicity-driven aggregation lighting circularly polarized luminescence of chiral gold clusters. Nano Res. 2020;13:3248-52.

40. Zhang MM, Dong XY, Wang ZY, Li HY, Li SJ, Zhao X, Zang SQ. AIE triggers the circularly polarized luminescence of atomically precise enantiomeric copper(I) alkynyl clusters. Angew Chem, Int Ed. 2020;59:10052-8.

41. Sugiuchi M, Maeba J, Okubo N, Iwamura M, Nozaki K, Konishi K. Aggregation-induced fluorescence-to-phosphorescence switching of molecular gold clusters. J Am Chem Soc. 2017;139:17731-4.

42. Xiao Y, Wu Z, Yao Q, Xie J. Luminescent metal nanoclusters: biosensing strategies and bioimaging applications. Aggregate. 2021;2:114-32.

43. Wu ZN, Yao QF, Zang SQ, Xie JP. Aggregation-induced emission in luminescent metal nanoclusters. Natl Sci Rev. 2021;8: nwaa208.

44. Wang D, Lee MMS, Shan G, Kwok RTK, Lam JWY, Su H, Cai Y, Tang BZ. Highly efficient photosensitizers with far-red/near-infrared aggregationinduced emission for in vitro and in vivo cancer theranostics. Adv Mater. 2018;30: e1802105.

45. Xu S, Yuan Y, Cai X, Zhang CJ, Hu F, Liang J, Zhang G, Zhang D, Liu B. Tuning the singlet-triplet energy gap: a unique approach to efficient photosensitizers with aggregation-induced emission (AIE) characteristics. Chem Sci. 2015;6:5824-30.

46. Lu Y, Xu YJ, Zhang GB, Ling D, Wang MQ, Zhou Y, Wu YD, Wu T, Hackett MJ, Hyo Kim B. Iron oxide nanoclusters for T1 magnetic resonance imaging of non-human primates. Nat Biomed Eng. 2017;1:637-43.

47. Gao S, Li T, Guo Y, Sun C, Xianyu B, Xu H. Selenium-containing nanoparticles combine the NK cells mediated immunotherapy with radiotherapy and chemotherapy. Adv Mater. 2020;32:1907568.

48. Dai J, Li Y, Long Z, Jiang R, Zhuang Z, Wang Z, Zhao Z, Lou X, Xia F, Tang BZ. Efficient near-infrared photosensitizer with aggregation-induced emission for imaging-guided photodynamic therapy in multiple xenograft tumor models. ACS Nano. 2020;14:854-66.

49. Guo B, Sheng Z, Hu D, Liu C, Zheng H, Liu B. Through scalp and skull NIR-II photothermal therapy of deep orthotopic brain tumors with precise photoacoustic imaging guidance. Adv Mater. 2018;30:1802591.

50. Liang G, Jin X, Zhang S, Xing D. RGD peptide-modified fluorescent gold nanoclusters as highly efficient tumor-targeted radiotherapy sensitizers. Biomaterials. 2017;144:95-104.

51. Liu J, Wu M, Pan Y, Duan Y, Dong Z, Chao Y, Liu Z, Liu B. Biodegradable nanoscale coordination polymers for targeted tumor combination therapy with oxidative stress amplification. Adv Funct Mater. 2020;30:1908865.

52. Xiong $X, X u Z$, Huang $H$, Wang $Y$, Zhao J, Guo $X$, Zhou S. A NIR light triggered disintegratable nanoplatform for enhanced penetration and chemotherapy in deep tumor tissues. Biomaterials. 2020;245: 119840.

53. Zhang J, Yang C, Zhang R, Chen R, Zhang Z, Zhang W, Peng SH, Chen X, Liu G, Hsu CS, Lee CS. Biocompatible D-A semiconducting polymer nanoparticle with light-harvesting unit for highly effective photoacoustic imaging guided photothermal therapy. Adv Funct Mater. 2017;27:1605094.

54. Ma N, Wu FG, Zhang X, Jiang YW, Jia HR, Wang HY, Li YH, Liu P, Gu N, Chen $Z$. Shape-dependent radiosensitization effect of gold nanostructures in cancer radiotherapy: comparison of gold nanoparticles, nanospikes, and nanorods. ACS Appl Mater Interfaces. 2017:9:13037-48.

55. Zhang XD, Wu D, Shen X, Chen J, Sun YM, Liu PX, Liang XJ. Size-dependent radiosensitization of $\mathrm{PEG}$-coated gold nanoparticles for cancer radiation therapy. Biomaterials. 2012;33:6408-19.

56. Dong X, Cheng R, Zhu S, Liu H, Zhou R, Zhang C, Chen K, Mei L, Wang $\mathrm{C}$, Su C. A heterojunction structured $\mathrm{WO}_{2.9}-\mathrm{WSe}_{2}$ nanoradiosensitizer increases local tumor ablation and checkpoint blockade immunotherapy upon low radiation dose. ACS Nano. 2020;14:5400-16.

57. Ni K, Lan G, Chan C, Quigley B, Lu K, Aung T, Guo N, La Riviere P, Weichselbaum RR, Lin W. Nanoscale metal-organic frameworks enhance radiotherapy to potentiate checkpoint blockade immunotherapy. Nat Commun. 2018;9:2351.

58. Susanne CSB, Michael L, Boris P. Quantitative sensing and signalling of single-stranded DNA during the DNA damage response. Nat Commun. 2019;10:944.

59. An D, Su J, Weber JK, Gao X, Zhou R, Li J. A Peptide-coated gold nanocluster exhibits unique behavior in protein activity inhibition. J Am Chem Soc. 2015;137:8412-8.

\section{Publisher's Note}

Springer Nature remains neutral with regard to jurisdictional claims in published maps and institutional affiliations.
Ready to submit your research? Choose BMC and benefit from:

- fast, convenient online submission

- thorough peer review by experienced researchers in your field

- rapid publication on acceptance

- support for research data, including large and complex data types

- gold Open Access which fosters wider collaboration and increased citations

- maximum visibility for your research: over $100 \mathrm{M}$ website views per year

At BMC, research is always in progress.

Learn more biomedcentral.com/submissions 